Portland State University

PDXScholar

"The Responsibility to Learn": an Investigation into the Language Ideologies of Young Women Speakers of Chinuk Wawa

Kelila Eichstadt

Portland State University

Follow this and additional works at: https://pdxscholar.library.pdx.edu/honorstheses

Let us know how access to this document benefits you.

Recommended Citation

Eichstadt, Kelila, "'The Responsibility to Learn": an Investigation into the Language Ideologies of Young Women Speakers of Chinuk Wawa" (2016). University Honors Theses. Paper 267.

https://doi.org/10.15760/honors.313

This Thesis is brought to you for free and open access. It has been accepted for inclusion in University Honors Theses by an authorized administrator of PDXScholar. Please contact us if we can make this document more accessible: pdxscholar@pdx.edu. 
"The responsibility to learn":

An investigation into the language ideologies of young women speakers of Chinuk Wawa

By

\section{Kelila Eichstadt}

An undergraduate honors thesis submitted in partial fulfillment of the

$$
\begin{aligned}
& \text { requirements for the degree of } \\
& \text { Bachelor of Arts } \\
& \text { in } \\
& \text { University Honors } \\
& \text { and }
\end{aligned}
$$

Applied Linguistics

Thesis Adviser

Tucker Childs

Portland State University 


\section{Abstract}

Chinuk Wawa is a language indigenous to the Pacific Northwest of the United States. Despite its status as an endangered language, Chinuk Wawa is being actively revitalized and developing more speakers as the initiative continues. The purpose of this inquiry is to demonstrate the complexity of language ideologies held in the Chinuk Wawa revitalization community, in particular that of young women (18-30 years old), whose participation is vital to the revitalization effort. This study revealed several themes in the language ideology of these Chinuk Wawa users: identity, authenticity, and responsibility. Identifying these themes contributes to further understanding the language's prospects and encourages further research on language ideology within the Chinuk Wawa community. 


\section{Acknowledgements}

I would like to take the time to thank several people in aiding my process in my first project featuring original research. I am grateful for the help of my thesis adviser, Tucker Childs, in navigating the research world of language ideology in endangered language and revitalization and the time spent reviewing my work and giving helpful feedback. Thanks to Kathy Cole for helping to point me in the right direction of possible interview participants and for helping to set up said interviews. I am grateful to all participants for taking the time out of busy schedules to supplement my research with their eloquent and candid answers to my interview questions. Thanks to the larger Chinuk Wawa language community for allowing me to spend time learning and researching your language. I hope this research will benefit the community. 


\section{Contents}

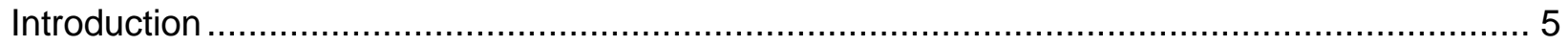

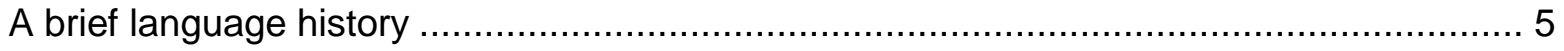

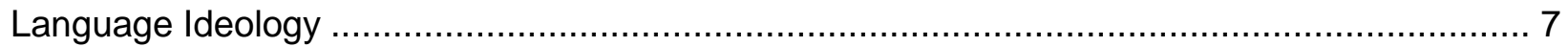

Toward a definition of "language ideology" ....................................................... 8

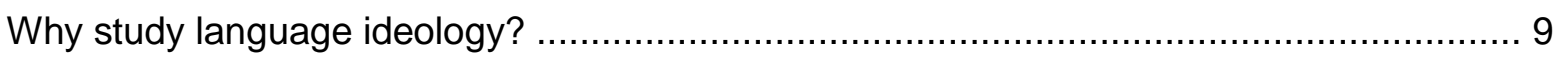

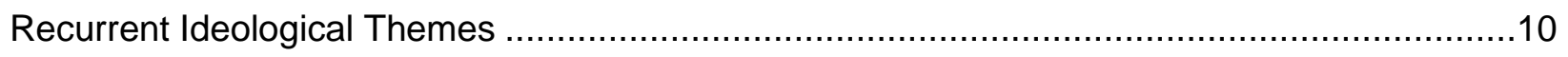

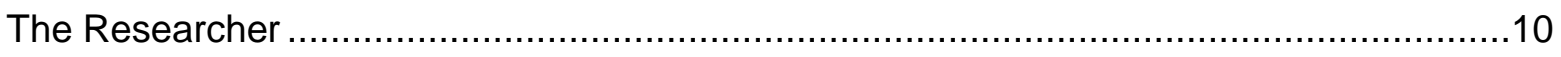

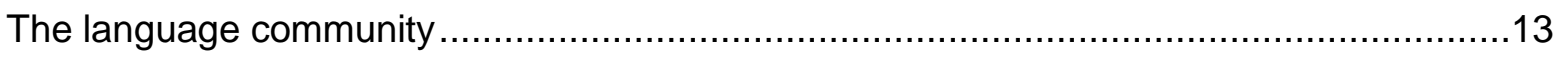

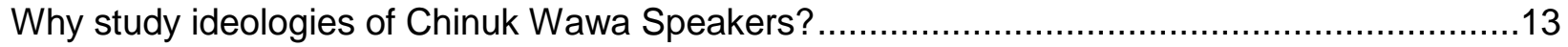

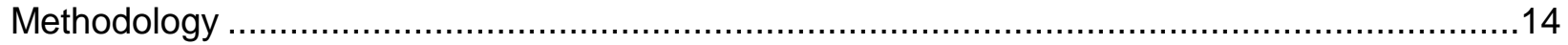

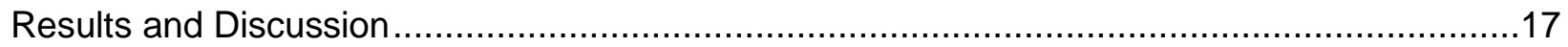

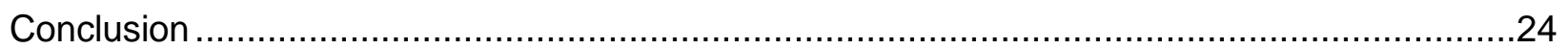

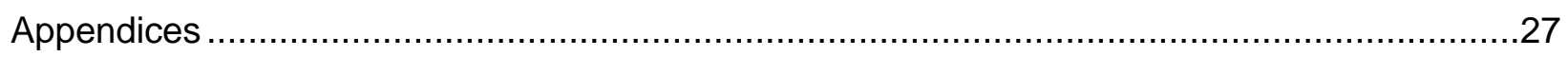

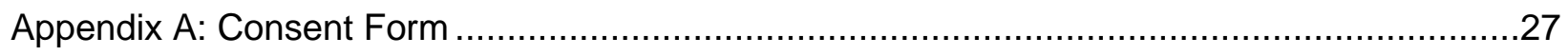

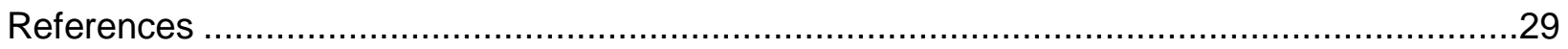




\section{Introduction}

Over the past twenty-five years, researchers in endangered languages have become increasingly concerned with issues in language ideology. Examinations of the social and cultural roots of ideologies and how they are transmitted have a foundational effect on the revitalization of these languages.

\section{A brief language history}

Chinuk Wawa is an "intertribal hybrid language indigenous to the Pacific Northwest" (Confederated Tribes of the Grand Ronde, 2012.) While the time and place of its origin remain contested among scholars, the language began as a pidgin used in trade between tribes in the Pacific Northwest and was also adopted by English and French-Canadian trappers for navigating the linguistic diversity of the area for trade. After the huge population decrease of indigenous peoples in the Pacific Northwest due to disease and likely genocide at the hands of colonizers, many of these languages began to decline in use. Chinuk Wawa, however, came to serve as a lingua franca for the region and as an important resource for communication among indigenous peoples speaking different languages, especially when later grouped together on reservations (Zenk \& Johnson, 2013.) Chinuk Wawa has been influenced by several languages, primarily those spoken in the area before the Europeans arrived. The official dictionary (The Confederated Tribes of the Grand Ronde, 2012) adds that large portions of vocabulary come from Chinookan and French. By 1856 and with the founding of the Grand Ronde Reservation, the language was well established in the region (The Confederated Tribes of the Grand Ronde, 2012.)

Later, it became necessary to speak English in order to survive and to find work. Boarding schools vilified Native tongues making it almost impossible for them to survive. One 
measure of Chinuk Wawa's success is that it has been adopted as a heritage language of The Confederated Tribes of Grand Ronde. Descendants of native speakers are working to maintain the language and develop even more speakers, especially among the youth of the community. As part of their cultural program, the Grand Ronde tribe offers an immersion language program for preschool, K-3, and two years of high school, for which students can receive both high school and college credit. In the community, there are several different classes throughout the week that are open to all ages. Classes also exist at other sites; Lane Community College in Eugene and the Grand Ronde Tribal Office in Portland hold classes open to the public.

I have been involved with the Chinuk Wawa community sporadically over the last few years in attending language classes at the Grand Ronde tribal office in Portland. Even with my small involvement in the Chinuk Wawa community, I have witnessed the considerable time and effort put into the language by many who seek to see it thrive. This includes instructors as well as students of the language taking time out of busy schedules to devote to teaching and learning. While beginning an exploration into what motivated these people, I wondered more specifically as to the involvement, perception, and feelings of young women in the revitalization of Chinuk Wawa. Because they represent a large chunk of the next generation of speakers, I wanted to ask how these young women feel about the revitalization of this language, why are they involved, what are their roles in the project, and are their voices being heard in the larger community? I hope to determine what effects the answers to these questions may have in the language maintenance process.

Attitudes, beliefs, and thoughts about the language are not homogenous and may differ within the Chinuk Wawa community. Due to social divisions, different backgrounds, and different feelings toward a language, conflict may arise within any revitalization project and may 
be the result of differing ideologies. With an understanding of the bases for these conflicts, one can examine them and perhaps reconcile the differences. This paper's purpose is to examine the ideologies of young women speakers of Chinuk Wawa and analyze how these ideologies may impact its revitalization. This study looks at female adult learners and speakers, first of all, because they are often not the focus of revitalization research, but also because they are vital to any revitalization effort. With this focus, however, other perspectives also appear, which can be evaluated in the same way, thus allowing for a full range of attitudes towards Chinuk Wawa and the revitalization effort.

Part of the explanation for neglecting the female perspective in the past may be that gender is not considered a relevant factor in revitalization, despite considerable evidence to the contrary (Hoffman, 2006, Leonard, 2012). The second reason for concentrating on young female enthusiasts is that they will be crucial to the revitalization effort, as they make up a large portion of the next generation of speakers. This project identifies a gap in the literature on language ideology and revitalization, especially with regard to formulations of identity, to indicate where further research and energies should be directed.

\section{Language Ideology}

The field of language research historically has been dominated by the ideologies of Western colonizers. In this framework, languages of the "colonized" are often deemed unimportant and inferior. Dorian (1998) describes the attitudes towards marginal and endangered languages as the western "ideology of contempt." Maintaining dominance motivated this ideology as it rose in conjunction with nationalism and the beginning of the industrial age. Linguistic "Social Darwinism" came into play, asserting that only the "fittest" languages will 
survive. This belief reinforces the attitude that some languages are superior to others, especially those spoken in Europe, where such beliefs flourished.

Starting in the field of anthropology in the late 1980s, the discourse on language ideology became more reflective in both anthropology and linguistics. Researchers are continuing to move away from practices originating in western colonial viewpoints and working to "decolonize" their methodologies (Smith, 1999), performing research for "everyone’s empowerment" (Cameron et al, 1992), but problems persist. Discourse on language ideologies and endangered languages continues to explore factors which inhibit the success of projects, especially with regard to research methodologies. Kroskrity (2009) has pushed researchers to examine the ideologies held by teachers, speakers, and learners of endangered languages in the same way.

\section{Toward a definition of "language ideology"}

Numerous definitions of "language ideology" exist. Austin \& Sallabank (2014) present a straightforward one seeing language ideology as a set of ideas and beliefs pertaining to a language. These beliefs and attitudes are often culturally determined. While speech communities have their own language ideologies, social divisions such as age and gender within a culture create a multiplicity of ideologies (Kroskrity, 2000). Many linguists and anthropologists stress the need to understand and recognize these differing viewpoints in order to reduce conflicts both within and outside of the community, and to ensure the success of a revitalization project (Cameron, 1992, Dauenhauer \& Dauenhauer, 1998, Hill, 2006, Rice, 2009.) 


\section{Why study language ideology?}

Linguists continue to cross the line as they move from researcher to language advocate. Ofelia Zepeda and Nora Dauenhauer are two leaders in this movement; they advocate for their ancestral languages while simultaneously researching them. Zepeda and Hill (1992) stress the necessity for linguists to turn their efforts and resources towards endangered indigenous languages in the United States, because they are worth the effort and not past saving. They stress the universal responsibility of humanity for the world's languages. Through her work with the Kaska $^{1}$ language, Meek (2010) portrays the importance of understanding the complexity of the contexts, beliefs, and social practices that create language ideology in understanding language shift and endangered languages in general. Chinuk Wawa is a similar language revitalization situation in which an examination of these contexts in respect to language ideology could benefit the understanding the language revitalization process.

Hill, however, in a later work questions the idea that everyone is responsible for the world's languages (2000.) She asserts that the notion of universal ownership undermines the advocacy of many language activists by commodifying languages. The language loses value in a global economy as just another endangered language, compared to its worth within its own local community. She instead advocates for language as a human right. With language death comes culture death, she argues, and access to one's own culture is a human right. Communities who have been and continue to be subject to colonization and forced assimilation have had their human rights taken away. Many are striving to regain them. Aiding communities in their struggle

\footnotetext{
${ }^{1}$ Kaska is a First Nations language whose speakers reside in British Columbia and the Yukon territories of Canada
} 
to access traditional and ancestral identities through the medium of their language supports the reclamation of human rights.

\section{Recurrent Ideological Themes}

The literature on language ideology and revitalization has identified common themes that occur across language revitalization projects. These can be divided into two groups: ideologies of the researcher/linguist and ideologies of the language community.

\section{The Researcher}

\section{Awareness}

Along with universal ownership, Hill (2002) discusses the ideas of hyperbolic valorization and enumeration and how they often undermine language advocacy. Hyperbolic valorization is the act of referring to endangered languages as "treasures" creating the idea that they have worth in all economies of the world. While these languages are valuable, they tend to be more so, if not only, to the language communities they stem from. According to Hill, enumerating languages by offering startling statistics about language death can be problematic, as "to census is an important gesture of power." Possessing statistics like these have historically been a common form of knowledge displayed by colonial regimes (Hill, 2002). Despite instances of conveying universal ownership, hyperbolic valorization, and enumeration being intended as a call to action, these tactics usually end with the commodification of language and a lower probability of successful revival. Spreading awareness of language endangerment can be valuable to attract resources for support of the project, but exaggerating its relevance to everyone in the world is not productive. Hill examined each endangered language project in order to 
identify local benefits of revitalization. Acknowledging that access to each individual's ancestral language is a human right goes much further in supporting the community than advocating for the world's endangered languages as a whole. Kroskrity (2009) argues that awareness of the actual effects of these tactics and the clarification of ideologies present in language renewal projects create a greater likelihood for success, as confrontations are eliminated or lessened before the project takes off, or at the least, they are made salient to the community.

\section{Positionality}

Kroskrity (2009) encourages researchers to communicate their positionality within a project. Framing yourself and your background within the community is crucial to navigating a project where many ideologies exist. For example, Battiste (1998) highlights the negative impact that a researcher from a Eurocentric training background can have in an indigenous language revitalization situation. She suggests that these researchers acknowledge their positionality and contribute by giving the community a framework that allows their voices to be heard. At the same time, she urges researchers to adopt a sideline position to the project.

\section{Multiplicity}

Many scholars in both linguistics and anthropology have accentuated the existence of multiple ideologies within a speech community. Beyond the differences in ideologies between linguist and community, social divisions such as age and gender create different internal ideological niches within a community. Dauenhauer \& Dauenhauer (1998) identify the complications a multiplicity of ideologies can create in a revitalization context. Nora Dauenhauer's perspective is unique as opposing the majority, as she is both an insider in the community as well as a researcher and language "expert." This allows her to have pre-existing insight into the language ideologies held by Tlingit speakers and how they impact language maintenance. 
While the overall consensus in the field seems to highlight the importance of linguist and community working together, Battiste (1998) encourages linguists to step in only to provide resources, as "ventriloquizing” (Ritchie, 1993) for a community can be detrimental to the progression of the community's goals. This support can encourage the voices of different social groups to establish themselves. For example, voices of young women are often damped due to the methodologies and frameworks of research emanating from a patriarchal society, as well as by forces within the society itself.

\section{Power}

The late 1980s brought language research methods under scrutiny (Rice, 2009). Cameron et al. (1992) began discussing issues of power and method in linguistic research. Field researchers were pushed to expand the way in which they thought about their research. Instead of documenting a dying language solely for the wealth and knowledge the study would contribute to the field, research should be done for and with the speech community whose language is being researched. Especially when dealing with endangered languages, the analyst must discuss the history of colonialism, and therefore power, as well as comparable dynamics within the community. Acknowledging your positionality is vital to begin a conversation. The goal is to use methodologies that empower a community rather than those that originate from an asymmetrical power dynamic. While Battiste (1998) and McCarty et al. (2006) do not directly respond to Cameron et al. (1992), their goals for decolonizing research and education methodologies for indigenous peoples accommodate each other. Rice (2009) supports Cameron et al.'s efforts with concrete examples of how linguist and community can work well together when ideologies, positionality, and power are openly discussed and research makes a shift to working for and with a community to meet common goals. With open communication everyone involved can put their efforts toward the same goal or recognize when they are not in accord and plan accordingly. 


\section{The language community}

Lee (2009) and Dementi-Leonard \& Gilmore (1999) are two examples of research studying the language ideologies present among the youth (e.g. young adults, high-school age) in language revitalization education settings. Lee focuses on the Navajo and Pueblo communities while Dementi-Leonard \& Gilmore details a project focusing on five traditional Athabascan languages. Lee identifies ideologies of respect, stigmatization and shame, marginalization, and agency and intervention. While the Dementi-Leonard \& Gilmore research does not precisely focus on language ideology, their examination of Athabascan language projects reveals feelings held by participants about self-determination and activism (what I would call feelings of responsibility) and pride regarding heritage.

These themes can serve as a guide for what may be present in similar research settings.

\section{Why study ideologies of Chinuk Wawa Speakers?}

Many languages of the Pacific Northwest are fading and will never be researched, documented, or revitalized. A few lucky ones have received attention from both linguist and community. Chinuk Wawa is one such language in the midst of a revitalization promulgated by The Confederated Tribes of Grand Ronde and affiliated linguists. The history and grammar of this language have been well analyzed, but there has been little discussion of the language ideologies governing the discourse engaged in by linguists and community. The role of youth and their language ideologies play in revitalization has been discussed in other speech communities (Battiste, 1998, Collins, 1998, McCarty, 2006), but tends to focus on educational settings of students in grades K-12. There seems to be a gap in the literature where a focus on language ideology of young women who have been active in the language revitalization in ways 
beyond that of required schooling. An examination of people grouped by their commonalities (for example, gender and age) could reveal the complexity and differences in language ideology within a single community.

Languages are dying off at a faster rate than linguists can conduct research on them, making it difficult for researchers to perform in-depth studies of language ideology, especially in terms of age and gender. Language ideology is a fairly recent field of interest. While great strides have been made in the ways in which these ideologies are analyzed, each community constitutes a unique situation, especially for the conflicts that may emerge. Modern language research stems from a past of Eurocentrism and (therefore) patriarchal methodologies. For many years, the field was dominated by men and thus little attention was given to women's language or beliefs about language. While language methodologies may be different in the Chinuk Wawa community, an examination of the power dynamic between men and women in the community is necessary and crucial for understanding the future of the language.

\section{Methodology}

The findings in this study are based on six semi-structured interviews with women who speak or are learning Chinuk Wawa. Five participants were young (18-30 years old) and one participant was older. ${ }^{2}$ All members identified themselves as Native American, four of whom are enrolled members of the Confederated Tribes of Grand Ronde. Six participants may be small, but nonetheless I feel is a representative sample that allows for an examination of the ideologies guiding women in their study of Chinuk Wawa. These women were identified through their

\footnotetext{
${ }^{2}$ This participant identified herself as an "elder" when asked her age.
} 
participation in the Chinuk Wawa language community, their interest in the revitalization of the language, and the recommendation of mutual peers in this community. My relationship to most of the participants was that of a fellow young female student of the language. While I have no Native American heritage, I began to learn the language because it was that of the place I have lived my entire life. Due to the commonalities among myself and the participants, I was able to establish immediate rapport and create a space where participants could be open and candid when answering interview questions.

Language fluency levels of participants ranged from intermediate to expert, determined by each speaker's own evaluation. Permission to conduct interviews regarding language ideologies was obtained from key members in the Chinuk Wawa language community ahead of time, as governed by the Portland State IRB (Human Subjects). In addition, each participant gave consent to participate in the interview (anonymously) and have their words recorded, transcribed, and analyzed. This consent was documented by their signature on a consent form. ${ }^{3}$

Between January and March of 2016, the interviews took place in quiet public spaces: cafés, student center commons, and museums. Each participant was interviewed alone, except for one case when two participants were interviewed together. Each interview was conducted in English and lasted 20-45 minutes. All interviews were recorded with a Zoom H1 audio recorder. I structured interviews by first asking general demographic questions, then proceeded to ask how they became acquainted with the language originally, their current involvement, and if and how their families and friends were or are involved with the language program. My goal was to create a space for participants to honestly share their thoughts, experiences, and feelings about the language, its role in their lives, and their role in the language program. I tried to elicit answers

\footnotetext{
${ }^{3}$ See appendix A
} 
that held clues for not only how the participant felt about the language, but also how they believed other members of their community felt about the language.

Some had experience in teaching the language and in educating others about the language. Those subjects I asked to detail experiences with their students to broaden the perspectives I sampled, for example, in detailing the attitudes of their students. I ended the interviews by asking more direct questions on the value and future of the language. I hoped that asking more general questions first would help the participant to relax and become comfortable with the format of the interviews, especially with the presence of a recording device. Being at ease would encourage them to be more honest and detailed as the questions became more direct.

Interviews were transcribed quickly after they took place in order to guarantee fidelity and to prepare them for close reading and analysis. Because the sample was relatively small, I was able to immediately note patterns across subjects. The information from interviews is supplemented by participant observation while attending Chinuk Wawa language classes at the Grand Ronde tribal office in Portland. Much of my attendance at these class occurred before I had begun research, but nonetheless helped to inform the establishment of my research questions.

Following the frameworks presented in Hatch (2002) and Dörnyei (2007), my analysis of the interview transcripts was done by selecting statements from each interview that revealed beliefs and attitudes towards Chinuk Wawa. These statements displayed commonalities around issues in identity, heritage, community, and sense of duty to the language, as detailed in the next section. 


\section{Results and Discussion}

Through the analysis of interview transcripts, several themes emerged from patterns that unfolded across interviews. These have been arranged into three categories: identity, authenticity, and responsibility. Being complex, identity can be further broken down into different levels, from individual to global. In the interest of the privacy of participants, I have not specified the names or ages of the attributed quotes. My goal here is to highlight common ideologies held by all or most participants across interviews, rather than focusing in on individual thoughts and feelings.

Every woman made an assertion that directly ties into how the language is a core component of their identity. This identity was not only as an individual, but includes familial, tribal, and even a wider identity as a Native American. Their feelings toward the language often came down to how it made each individual feel when producing Chinuk Wawa sounds and words. When asked if she liked speaking Chinuk Wawa, one participant responded with,

I do. It's actually a lot. It feels a lot, it feels good, if this makes sense, it feels good in the mouth to speak it. It's not something that's foreign. It feels authentic when you speak it. It feels like you're supposed to be and so I don't dislike speaking it I like speaking it and I feel like I'm using a different part of my brain, if that makes sense, too.

Identity can be found even when it comes down to the sounds of a language. This individual reveals that speaking the language allows for feelings of authenticity. Perhaps this is a way to access one's authentic self, by speaking the language in the place it grew out of and in tasting 
your ancestor's words on your own tongue. For many, the language was only a generation or two away. Learning it now allows these women to reflect on the memories and stories told to them about how their grandparents used the language:

And I realize that me and my sister are utilizing the language in exactly the way that my great-great-grandma did which was just to gossip with her sisters when they don't want anyone to know what they were saying. So I think we're actually doing the language a little bit of a service in using it exactly the way they did.

The idea of authenticity allowed one woman to stand up to those telling her to speak English when she was trying to practice Chinuk Wawa: "But it was funny, if somebody did say something I would be like, Um, I'm speaking a Native language. This is the original language so you can't say anything." While a history of boarding school oppression and stigma against Native Languages has created a sense of shame at speaking one's own language, these women do not appear even slightly ashamed. Authenticity is a theme cited as a right to be accessing, speaking, and thereby maintaining Chinuk Wawa. Multiple women stressed that it's "cool to speak your language."

Throughout our conversations, the women revealed that Chinuk Wawa is not held in high esteem by all members of the community. This is often due to ideas about language purity. Parts of the community believe that Chinuk Wawa is not a "traditional" language. It is not "our" language and therefore the time should not be put into maintaining it. Because of these assertions, many believe that the language will not survive. When members of a community lack hope for the future, this often results in a negative impact on the rate of success for revitalization. 
In a different regard, some differentiate Chinuk Wawa and Chinuk Jargon. While "jargon" often holds negative connotations and speaks to the incompleteness or restrictiveness of the language, here it seems to contrast traditional and modern ways of speaking the language. Some women communicated their frustration with members of the community resistant to change in the language, such as coining new words and phrases to allow the language to be used in modern situations. With resistance to such innovations, it is difficult to keep a language alive, as languages are constantly changing. One woman hopes people holding these beliefs realize that it is necessary for a language to incorporate modern concepts in order to be used in everyday life.

I think it's just hard for people to realize that the language does need to evolve because there's so much new technology, so much new... we didn't have cell phones back in the day so we had to create and coin new words for that, and I think that's hard for people to understand.

Although the language is continuing to change, it is important to learn its history. Language classes often offer access to not only how to speak the language, but to the cultural context of the language. Due to the pervasiveness of English and Western history in the school systems of the United States, Native students do not often have the chance to learn about the history of their tribe and ancestry in school. When it is present, the Native American history is often a brief segment in the white-dominated history curriculum of the school year. Studying Chinuk Wawa often allows young Native Americans to learn about themselves and the history of their culture. Knowing its history and stories allows them to know themselves more completely, helping to create not only confidence, but also to care for it and safeguard it. Learning about the 
history of the language is one factor that has led students to become more passionate in maintaining their heritage language.

Some students begin to learn Chinuk Wawa and through it find ways to access their own heritage language. Learning about another culture often makes them curious to learn about their own. Seeing others devoted to and successfully learning their language (and having fun with it) allowed many to see it is possible to do the same with their own ancestral languages, whether they are endangered or not.

And so it wasn't just a class for us, it felt like I could actually do something for my people. Because when we didn't learn, we weren't taught our own languages, but we want to. And so there's that loss of understanding. Religion, or some of those things that are in your cultural ways that tie to the language. We don't have that. And so just knowing that you could do something instead of just being like Oh I don't speak the language. Like doing something about it was the real big thing for me. And I could tell that they had passion for it. Because they knew that they could use it for their own languages, too.

Speaking a Native Language, even though it may not be your heritage language, allows for an entry point to begin to heal the trauma caused by colonization.

Even though I'm not Grand Ronde or one of those tribes, it's just speaking a Native language. I can't explain why it makes me happy, but it does. It's kind of like taking-back and reclaiming. Or I guess what it is, is decolonizing. Decolonizing yourself, in the language sense. Which is hard to do. 
While some participants expressed uncertainty as to the future of Chinuk Wawa, most participants emphatically and without hesitation asserted that the language does indeed have a strong and bright future. Many expressed hopes for expanded language programs and creating more speakers

Observing non-tribal members with an investment in the language, as well as the passion demonstrated by tribal members, further increases the perceptions of the positive value of the language. This is true inside the tribal community as well as outside. The uniqueness of the language creates curiosity and brings people together in situations that often creates bonds. One woman remarked on the intimacy intrinsic in learning a language with other people. Trust has to be formed not only because you are trying something new and might say something wrong, but because the deep significance of sharing a language, your identity, and your stories with an outsider is no small feat.

Speaking a language with so few speakers in relation to dominant languages can often create situations in which the separateness of the group is accentuated. As with any language that other people do not speak, there is a risk that people might think you're talking about them or gossiping when using the language in their presence. The women relayed stories of this happening not only with those completely unfamiliar with the language, but also with friends and tribal members who know of the language but do not speak it. This situation is a difficult one to remedy, but some speakers approach these situations with a devil-may-care attitude, "It's cool to be able to talk about someone and them not know what you're saying. (laughter) Just kidding. I'm not, but kind of (laughter)." Perhaps this use of a language will motivate others to learn in order to find out what is being said. There is beauty in a balance of using your language in 
multiple realms of life. After all, can you really say you know a language intimately if you can't use it to gossip?

A responsibility to maintain the language is a strong theme underlying the discussion of the language. Each woman discussed the idea of transmitting the language to any children they do or may have. A common goal is to teach Chinuk Wawa alongside English to their children in order to ease access to the language and allow it to become second nature. Teaching children creates more speakers and more appreciation of the language. It instills the language as part of the child's identity, and motivates protection of the language for future generations. Women who are not Grand Ronde tribal members also had the urge to pass the language on to the children but were not confident that they had the right to do so.

I would love to teach my children an indigenous language and I could do that with Chinuk Wawa. It's there, right? And then I'm like, but that's not okay. It's not okay for me to teach somebody else's language to my children. So then I find myself in this pickle of investing this time into this language but then I don't get to do anything with it because it's not mine. And that makes me sad.

This idea leaves many non-heritage speakers at a loss. While many often advocate for more speakers of the language, the hope is to be able to accomplish this goal without commodifying the language itself. Much of the power of the language comes from how much it means to the culture and identity of those who speak it and whose ancestors have spoken it in the past. If the language is taught to those without an understanding for this culture, will it retain its value? Perhaps it is possible with education and attention, but can this be done alongside language maintenance in general? 
While the idea of transmission to non-Grand Ronde children remains a difficult subject, the women are open to speakers of all backgrounds learning the language. One woman (who identified herself as a Grand Ronde tribal member) described her experience in a classroom setting where people from many different backgrounds gathered to spend time learning about the language and culture,

It was a good group of students that were really dedicated, whether they were Native or not, to the language. Which as a tribal member, it kind of makes your... (pause) It kind of sounds corny to say, but it makes your heart feel good. It makes you feel good that people who aren't tribal citizens are investing in the language that you are so invested in yourself.

This generation is feeling the pressure to take up the reins and ensure the language will continue to be propagated and be passed down to future generations. The ancestors of many speakers were often punished when speaking Chinuk Wawa; these women now feel it is important to take advantage of their privilege to learn the language without fear of punishment. A sense of duty to keep heritage and culture alive is increasingly present.

I don't want to say I feel the obligation to learn it, but I feel the responsibility to learn it. I feel like it's my responsibility as first a tribal citizen but also as my grandma's granddaughter to know it and to learn it and to be involved with it.

Urgency combined with feelings of responsibility in regard to many levels of identity are galvanizing this generation to dedicate time to maintaining the language and further developing 
the language program for children as well as adults. For some women, the belief is that it's now or never for the proliferation of fluent speakers. The sense of identity and responsibility of the language is so powerful in these women that it was almost never even a choice to dedicate their lives to protecting it,

I think about my ancestors and the people before me and all the effort they did to preserve this language. It's the reason we have it now. So I feel that this is my obligation. I almost feel like the language chose me... I literally feel like the language chose me and that's my job. That's my obligation to my tribe is to work as hard as I can to fulfill what my ancestors started... You know, you think about the people that were here before you. You don't want to let them down.

\section{Conclusion}

While this research hinted at an even more complex set of ideologies than those presented here, those of identity, authenticity, and responsibility were the strongest and most commonl themes suggested. More research is necessary in order to build a more detailed impression of the multitude of thoughts, feelings, and beliefs circling the language community.

This research points to the complexity of language ideologies held by each individual in a language revitalization project and the role Chinuk Wawa plays in the identities of the young women involved in the revitalization effort. While the language community is continuing to grow in terms of the absolute number of speakers, my sample size is sufficient to begin with the identification of the ideologies held by young female speakers. It is important to understand the language beliefs they hold in order to understand whether their perceptions of the language and 
motivations for pursuing fluency and transmission of the language will persist. The ultimate goal, then, is to understand the role they and their beliefs will play in the revitalization effort.

The data collected indicates that the language plays a large part in the multi-faceted identity of the young women who dedicate time to learn it. Through learning the language, speakers can access the history of their ancestors and transmit the language to future generations. The participants revealed an array of attitudes toward the language held by themselves and other members of the community, suggesting directions for future research.

One such direction could be a longitudinal study of children participating in the Chinuk Wawa immersion program in Grand Ronde, especially as the program expands to include more grade levels. Such a study could indicate when and why particular language ideologies are formed. Meek (2010) argues that anyone concerned with minority languages should also be concerned with the way speakers are being socialized into the language. Understanding how particular ideologies are formed through different socialization methods could contribute to fashioning endangered language pedagogy and have a positive impact on the future of Chinuk Wawa.

Much of existing research in language ideology regarding revitalization focuses on the role of education and on youth. While I agree that younger generations have a prominent role in the future of the language, it may be beneficial to research existing ideologies of all genders and ages in order to pinpoint the variety of attitudes and beliefs held by members of the larger community in relation to the language and if these are being transmitted to younger generations. Conducting interviews with a range of ages and genders regarding their language ideologies and analyzing similarities and differences between these groups could reveal how, when, and why some ideologies are transmitted while others seem to form themselves. 
This research shows the passion for Chinuk Wawa and the dedication of its students. As participants asserted, it is important to reveal why and how people are pursuing study of the language. Doings so allows for a dialogue and a place for the larger community to understand the importance of the language and why it is worth the time and effort to sustain it. 


\section{Appendices}

\section{Appendix A: Consent Form}

\section{Young Women Speakers of Chinuk Wawa: Language Ideologies and Their Effect on its Revitalization Consent Form}

You are being invited to participate in a research study about ideologies (thoughts, beliefs, etc.) of young women speakers and learners of Chinuk Wawa. This study is being conducted by Kelila Eichstadt, an undergraduate student at Portland State University. This study will serve as her thesis project, in order to complete her degree requirements for the honors program.

There are no known risks if you decide to participate in this research study. There are no costs to you for participating in the study. The information you provide will be used to gain understanding of the thoughts and beliefs young women of the language community hold in regards to the Chinuk Wawa language. The information collected may not benefit you directly, but the information learned in this study hopes to provide more understanding to the general language community in order to aid revitalization of the language.

The data of the study will be coded to protect the identities of participants. Names and personal information of participants will not be divulged in the analysis and final write-up of the project. The interviews will be stored on a password protected computer. Participants will be given the opportunity to review the interview recordings and have anything removed that they do not wish to have present in the data. Participants will be given the option of reviewing the final product of the research.

Your participation in this study is voluntary. By signing this form, you consent to an interview and the possibility to be contacted for follow-up interviews. You are free to decline to answer any question during the interview or withdraw participation without penalty.

If you have any questions about the study, please contact:

Kelila Eichstadt kelila@pdx.edu (503) 313- 8864

or her thesis project adviser

Tucker Childs

childst@pdx.edu

(503) 725-4099

UCB $335 \mathrm{H}$

The Portland State University Institutional Review Board has reviewed this project. If you have any concerns about your rights in this study, please contact the PSU Office of Research Integrity at (503) 7252227 or email hsrrc@pdx.edu. 
(Signed)

(Print) 


\section{References}

Austin, P. K., \& Sallabank, J. (Eds.). (2014). 'Introduction' in Endangered Languages: Beliefs and Ideologies in Language Documentation and Revitalisation. Oxford, UK: Oxford University Press British Academy.

Battiste, M. (1998). Enabling the autumn seed: Toward a decolonized approach to Aboriginal knowledge, language, and education. Canadian Journal of Native Education, 22(1), 16.

Cameron, D., Frazer, E., Harvey, P., Rampton, M. B. H., \& Richardson, K. (1992). 'Introduction' in Researching Language: Issues of Power and Method. London and New York: Routledge.

Confederated Tribes of the Grand Ronde. (2012). Chinuk Wawa: kakwa nsayka ulman-tilixam laska munk-kemteks nsayka = As our elders teach us to speak it. Distributed by University of Washington Press.

Collins, J. (1998). Our Ideologies and Theirs. Pragmatics, 2, 3-405.

Dauenhauer, N. M., \& Dauenhauer, R. (1998). Technical, emotional, and ideological issues in reversing language shift: Examples from Southeast Alaska. Endangered languages: Current issues and future prospects, 57-98.

Dementi-Leonard, B., \& Gilmore, P. (1999). Language Revitalization and Identity in Social Context: A Community- Based Athabascan Language Preservation Project in Western Interior Alaska. Anthropology \& Education Quarterly, 30(1), 37-55.

Dorian, Nancy. (1998). Western Language Ideologies and Small-Language Prospects. In Endangered Languages: Current Issues and Future Prospects. Lenore A. Grenoble and Lindsay J. Whaley, eds. Pp. 3 - 21. Cambridge: Cambridge University Press.

Dörnyei, Z. (2007). Research methods in applied linguistics: Quantitative, qualitative, and mixed methodologies. Oxford University Press.

Hatch, J. A. (2002). Doing qualitative research in education settings. SUNY Press.

Hill, J. H. (2002). "Expert rhetorics" in advocacy for endangered languages: who is listening and what do they hear? Journal of Linguistic Anthropology, 12(2), 119-133.

Hill, J. H.(2006). Ethnography of language and language documentation. In J. Gippert, N. P. 
Himmelmann \& U. Mosel (Eds.), Essentials of Language Documentation (pp. 113-128). Berlin: Mouton de Gruyter.

Hoffman, K. E. (2006). Berber language ideologies, maintenance, and contraction: Gendered variation in the indigenous margins of Morocco. Language \& communication, 26(2), 144-167.

Kroskrity, P. V. (2000). Regimenting Languages: Language Ideological Perspectives. In Regimes of language: ideologies, polities, and identities. Kroskrity, P. V. (Ed.). James Currey Publishers.

Kroskrity, P. V. (2009). Language Renewal as Sites of Language Ideological Struggle. The Need for" Ideological Clarification. Indigenous Language Revitalization: Encouragement, Guidance \& Lessons Learned Flagstaff (Arizona): Northern Arizona University, 71-83.

Kroskrity, P. V., \& Field, M. C. (Eds.). (2009). 'Introduction' in Native American language ideologies: Beliefs, practices, and struggles in Indian country. University of Arizona Press.

Lee, T. S. (2009). Language, identity, and power: Navajo and pueblo young adults' perspectives and experiences with competing language ideologies. Journal of Language, Identity, and Education, 8(5), 307-320.

Leonard, W. Y. (2012). Framing language reclamation programmes for everybody's empowerment. Gender and Language, 6(2), 339-367.

McCarty, T. L., Romero, M. E., \& Zepeda, O. (2006). Reclaiming the gift: Indigenous youth counter-narratives on Native language loss and revitalization. The American Indian Quarterly, 30(1), 28-48.

Meek, Barbra A. We Are Our Language: An Ethnography of Language Revitalization in a Northern Athabaskan Community. Tucson: U of Arizona, 2010. Print.

Rice, K. (2009). Must there be two solitudes? Language activists and linguists working together.

Ritchie, S. (1993). Ventriloquist Folklore: Who Speaks for Representation? Western Folklore, 52(2/4), 365-378.

Smith, L. T. (1999). Decolonizing methodologies: Research and indigenous peoples. Zed books.

Woolard, K., \& Schieffelin, B. (1994). Language Ideology. Annual Review of Anthropology, 23, 
$55-82$.

Zenk, Henry B., Johnson, Tony A. (2013). In Chinookan Peoples of the Lower Columbia. Boyd, Robert T., Kenneth M. Ames, and Tony A. Johnson eds. Seattle, WA: University of Washington Press.

Zepeda, Ofelia, and Jane H. Hill (1992). The Condition of Native American Languages in the United States. In Endangered Languages. Robert H. Robins and Eugene M. Uhlenbeck, eds. Pp. 135-156. Oxford: Berg. 